\title{
After-School Physical Activity Interventions on Child and Adolescent Physical Activity and Health: A Review of Reviews
}

\author{
Yolanda Demetriou1, Fiona Gillison ${ }^{2}$, Thomas L. McKenzie ${ }^{3}$ \\ ${ }^{1}$ TUM School of Sport and Health Science, Department of Sport \& Health Education, Technical University of Munich, Munich, \\ Germany \\ ${ }^{2}$ Department for Health, University of Bath, Bath, UK \\ ${ }^{3}$ School of Exercise and Nutritional Sciences, San Diego State University, San Diego, USA \\ Email:yolanda.demetriou@tum.de,F.B.Gillison@bath.ac.uk,tmckenzie@sdsu.edu
}

How to cite this paper: Demetriou, Y., Gillison, F., \& McKenzie, T. L. (2017). After-School Physical Activity Interventions on Child and Adolescent Physical Activity and Health: A Review of Reviews. Advances in Physical Education, 7, 191-215. https://doi.org/10.4236/ape.2017.72017

Received: April 6, 2017

Accepted: May 23, 2017

Published: May 26, 2017

Copyright ( 2017 by authors and Scientific Research Publishing Inc. This work is licensed under the Creative Commons Attribution International License (CC BY 4.0).

http://creativecommons.org/licenses/by/4.0/ (c) (i) Open Access

\begin{abstract}
Schools are a critical setting for children to accrue recommended levels of physical activity, and after-school programmes are suggested to supplement existing programmes such as physical education. This review of reviews provides a comprehensive picture of the effects of after-school physical activity programmes on student physical activity and health. We completed a literature search of electronic databases and identified six existing systematic reviews and meta-analyses of the effects of after-school programmes on child and adolescent physical activity and health. We compared these reviews on numerous factors, including the databases searched, aims, outcome variables, physical activity measures, inclusion criteria, and quality of original studies. Our review of reviews identified considerable differences among the published reviews in the number and type of studies included, and in the conclusions drawn. In general, the reviews identified better outcomes when conducting the programmes in school rather than community settings, providing sessions on two or more days a week, and ensuring high programme attendance rates. Subgroup analyses indicated that girls were more receptive than boys to intervention programmes that promoted weight control. Additionally, there were some benefits for increasing physical activity levels among overweight youth and boys. This review of reviews suggests there is currently only modest support of the benefits of after-school programmes on child and adolescent physical activity levels and body composition. Many questions remain unanswered, and there is further need to design, implement, and assess quality after-school interventions that target physical activity in diverse settings.
\end{abstract}

\section{Keywords}

After-School, Physical Activity, Health, Review of Reviews 


\section{Introduction}

Physical activity in childhood and adolescence is associated with improved physical and psychological health (Poitras et al., 2016). As both physical activity and obesity commonly track from childhood into adulthood (Telama et al., 2005), establishing strong habits for engaging regularly in physical activity during childhood and adolescence is vital to the prevention of obesity and chronic diseases such as diabetes and heart disease. The World Health Organisation (WHO, 2010) recommends a daily minimum of 60 minutes of moderate to vigorous physical activity (MVPA) for children and adolescents for health benefit. In 2015, the Health Behaviour in School-aged Children (HBSC) survey indicated that only $13.9 \%$ of children and adolescents across 32 countries from Europe and North America met this recommendation (Kalman et al., 2015). This is supported by accelerometer data from over 27,000 children and adolescents (aged 3 to 18) from 20 studies in ten countries which showed that only $9 \%$ of the boys and $2 \%$ of the girls met the WHO recommendations (Cooper et al., 2015).

The prevalence of physical inactivity in childhood underscores the need for widespread efforts to promote regular physical activity at an early age. Schools have been identified as important settings for promoting physical activity in youth (Centers for Disease Control and Prevention, 2013; Kahan \& McKenzie, 2015; Sallis et al., 2012; US Department of Health and Human Services, 2013). In high- and middle-income countries, nearly all children attend schools, most of which provide some opportunities for engaging in both structured and unstructured physical activity. Many countries have established time and other requirements for physical education in schools. In the UK, for example, there is a requirement for schools to provide at least two hours per week of physical education for all children aged from five to 16 (Department of Education, 2013). In Germany, three 45-minute physical education classes are recommended per week to average approximately 100 weekly minutes of physical education (Deutscher Olympischer Sportbund, 2006). At the same time, schools are facing increased pressure to meet academic demands and thus frequently fall short of providing the mandated or recommended time allocations for physical education (Kelder et al., 2005). For example, data from the 2014 School Health Policies and Program Study (SHPPS) in the USA indicated that only 3.7\% of schools provided the required daily physical education for the entire school year (U.S. Department of Health and Human Services, 2015).

With physical education not providing sufficient opportunities for children to achieve the recommended amounts of MVPA, other sources of physical activity need to be identified and there has been an increase in the number of after-school physical activity programmes. For example, nearly half $(43 \%)$ of US youths participate in some form of after-school programme (Branscum, Sharma, Wang, Wilson, \& Rojas-Guyler, 2013) and in the UK over 90\% of primary schools offer after-school programmes at least one day a week (Davies, Wood, Banfield, Edwards, \& Jago, 2014).

There is no single accepted definition of what constitutes an after-school 
physical activity programme, but it is implicit that they include supervised activities directly after school, usually on school premises and open to all children. Nonetheless, the programmes may also be conducted in community settings, often through collaboration between schools and community organisations. Programmes may be delivered by teachers, school or community staff, and/or volunteers. As the programmes occur beyond the regular school day, they are subject to fewer state or national mandates than physical education and thus function with greater flexibility (e.g., for time allocations, activity content, and teacher/supervisor qualifications). In contrast to physical education which is required by law and has a mandated curriculum, after-school programmes are typically locally designed and participation in them is voluntary. These programmes are also different from sports clubs and interscholastic programmes; for example they are non-selective of participants, not focussed on a single competitive sport, and function primarily to provide continuous childcare and supervision rather instruction on a specific skill or performance. Physical activity is sometimes the sole focus of an after-school programme, but it is usually only one component of a multifaceted extracurricular or enrichment programme.

Compared to physical education, research on after-school programmes is in its infancy. Nonetheless, six reviews of the effectiveness of after-school programmes were published between 2009 and 2016 (Atkin, Gorely, Biddle, Cavill, \& Foster, 2011; Beets, Beighle, Erwin, \& Huberty, 2009; Branscum \& Sharma, 2012; Mears \& Jago, 2016; Pate \& O’Neill, 2009; Vasques et al., 2014). These reviews, authored by people from diverse countries, varied in their focus (e.g., on selected outcome variables such as physical activity or BMI) and did not all include the same studies or generate the same conclusions. Thus, the purpose of this paper is to provide a "review of reviews" in order to identify differences and commonalities among the previous review articles (e.g., content focus, conclusions) as well as to synthesize the results of studies on the effects of after-school physical activity programmes on child and adolescent physical activity and health.

\section{Methods}

We completed our literature search in June 2016. In line with standard practice (Higgins \& Green, 2008) and to include a comprehensive set of sources, we searched the following seven databases: ISI Web of Knowledge, PsycInfo, MedLine, PsyndexPlus, Academic Search Premier, ERIC, and SportDiscus. We searched on article title, abstract, and keywords using the following search terms: (after-school or extracurricular) and (intervention* or program ${ }^{*}$ ) and (physical activit $^{\star}$ or sport $^{\star}$ or exercise $e^{\star}$ ) and (child ${ }^{\star}$ or pupil ${ }^{\star}$ or boy ${ }^{\star}$ or girl or student ${ }^{\star}$ or adolescent ${ }^{*}$ ).

We selected articles for detailed analysis if they met the following criteria: 1) a review article (systematic review or meta-analysis); 2) reported the relationship between physical activity after-school programmes and physical activity levels, sedentary behaviour, and/or health parameters (e.g., body composition, physical 
fitness, blood lipids, psychological determinants of wellbeing); 3) conducted with school-aged children or adolescents with no known physical health limitations up to and including 19 years; and 4) written in English. All titles and abstracts were screened for inclusion by the first author; following this, full texts of potentially relevant papers were divided into two groups and screened independently by two researchers based on the inclusion criteria.

\section{Results}

The search identified 1317 articles, and after removing 175 duplicates, we screened 1142 articles. Of these, six fulfilled the inclusion criteria and were included in this review of reviews (see Figure 1 and Table 1).

\subsection{Summary of the Reviews of Programme Effectiveness Studies}

Pate and O'Neill (2009) reviewed 12 after-school intervention studies aimed at increasing children's physical activity, four of which (33.3\%) showed significant positive results. A strength of their review was the inclusion of nine studies that used objective measures of physical activity (six used accelerometers, two used direct observation, and one used heart rate monitors). Three of the nine objectively measured studies reported a significant increase in physical activity (Kelder et al., 2005; Martínez Vizcaíno et al., 2008; Weintraub et al., 2008), and three others reported a trend towards increasing it. The outcomes varied according to study design, with two (Barbeau et al., 2007; Weintraub et al., 2008) of seven

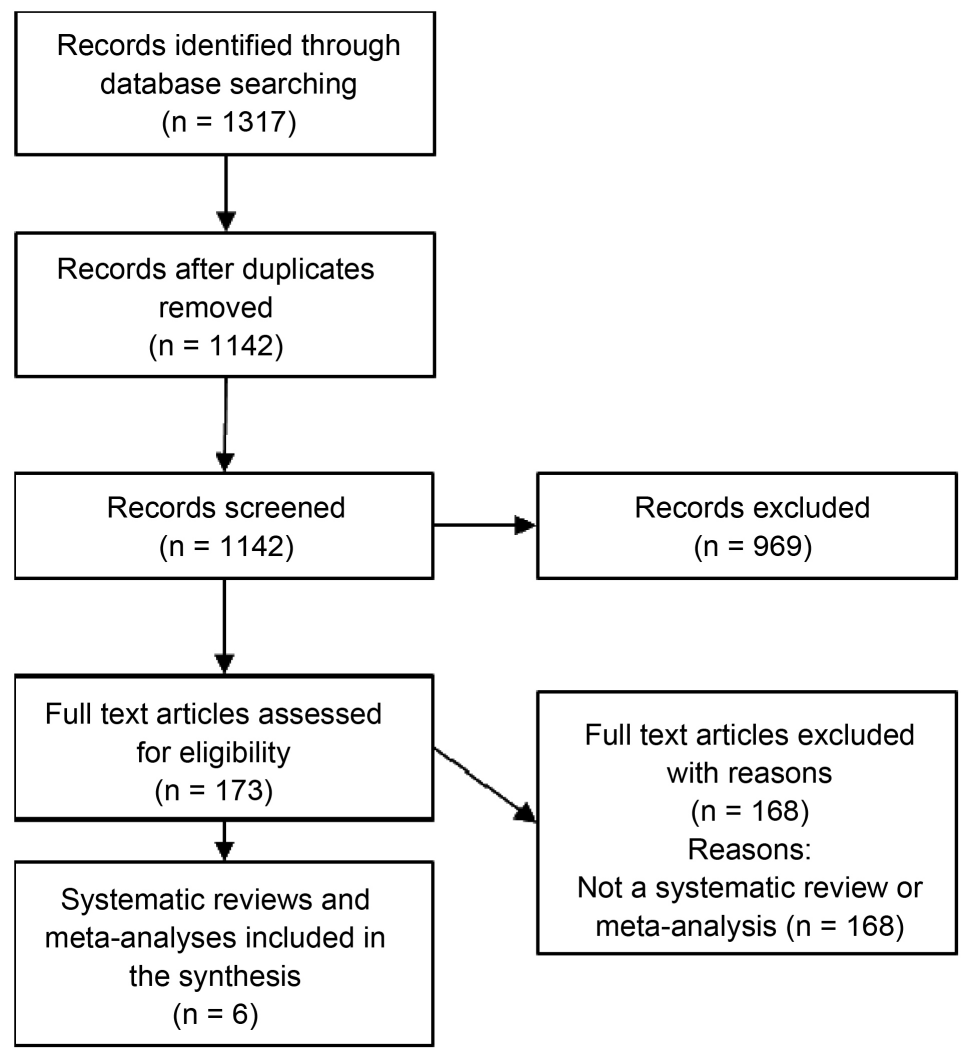

Figure 1. Identification of included systematic reviews and meta-analyses. 
Table 1. Overview of systematic reviews of after-school physical activity programmes on children's physical activity and health.

\begin{tabular}{|c|c|c|c|c|c|c|}
\hline & $\begin{array}{l}\text { Pate \& O'Neill } \\
(2009)\end{array}$ & $\begin{array}{l}\text { Beets et al. } \\
(2009)\end{array}$ & $\begin{array}{l}\text { Atkin et al. } \\
\text { (2011) }\end{array}$ & $\begin{array}{l}\text { Branscum \& } \\
\text { Sharma (2012) }\end{array}$ & $\begin{array}{l}\text { Vasques et al. } \\
\text { (2014) }\end{array}$ & $\begin{array}{l}\text { Mears \& Jago } \\
(2016)\end{array}$ \\
\hline $\begin{array}{l}\text { Inclusive } \\
\text { dates }\end{array}$ & Not stated & $\begin{array}{l}\text { 1980-February } \\
2008\end{array}$ & $\begin{array}{l}\text { 1990-March } \\
2010\end{array}$ & $2006-2011$ & $2000-2011$ & $1950-2015$ \\
\hline $\begin{array}{l}\text { Databases } \\
\text { searched }\end{array}$ & $\begin{array}{l}\text { Medline } \\
\text { Psyc-Info }\end{array}$ & $\begin{array}{l}\text { PubMed } \\
\text { EBSCOhost } \\
\text { ScienceDirect }\end{array}$ & $\begin{array}{l}\text { Medline } \\
\text { SPORTDiscus } \\
\text { PsychINFO; } \\
\text { Cochrane } \\
\text { Database of } \\
\text { Systematic } \\
\text { Reviews; } \\
\text { Database of } \\
\text { Abstracts of } \\
\text { Reviews of } \\
\text { Effectiveness; } \\
\text { Cochrane } \\
\text { Central } \\
\text { Register of } \\
\text { Controlled } \\
\text { Trials; } \\
\text { EMBASE; } \\
\text { CINAHL; } \\
\text { HMIC; } \\
\text { ASSIA; } \\
\text { SIGLE; } \\
\text { Current } \\
\text { Contents; } \\
\text { ERIC; } \\
\text { TRANSPORT; } \\
\text { Environline; } \\
\text { EPPI Centre } \\
\text { Databases; } \\
\text { NRR }\end{array}$ & $\begin{array}{l}\text { Medline } \\
\text { SPORTDiscus } \\
\text { Academic Search } \\
\text { Premier } \\
\text { Health } \\
\text { Source-Consumer } \\
\text { Edition } \\
\text { Health Source: } \\
\text { Nursing/Academic } \\
\text { Edition }\end{array}$ & $\begin{array}{l}\text { PubMed } \\
\text { Medline } \\
\text { List at EBSCO } \\
\text { (Academic Search } \\
\text { Complete) } \\
\text { Web of science } \\
\text { (Current Contents } \\
\text { Connect), } \\
\text { Latindex } \\
\text { SciELO.org } \\
\text { Editors: Elsevier, } \\
\text { Wiley, Springer, } \\
\text { Taylor \& Francis }\end{array}$ & $\begin{array}{l}\text { Medline } \\
\text { Embase } \\
\text { PsychINFO }\end{array}$ \\
\hline $\begin{array}{l}\text { Search } \\
\text { terms }\end{array}$ & $\begin{array}{l}\text { 1) after-school } \\
\text { 2) physical } \\
\text { activity } \\
\text { 3) intervention }\end{array}$ & $\begin{array}{l}\text { 1) after-school } \\
\text { program; } \\
\text { school-based } \\
\text { setting } \\
\text { 2) physical } \\
\text { activity behavior } \\
\text { 3) study design } \\
\text { (intervention, } \\
\text { quasi, or } \\
\text { controlled) }\end{array}$ & $\begin{array}{l}\text { 1) community, } \\
\text { gym } \\
\text { 2) physical } \\
\text { activity, exercise, } \\
\text { play } \\
\text { 3) child, } \\
\text { adolescent, youth }\end{array}$ & $\begin{array}{l}\text { 1) after school } \\
\text { 2) obesity } \\
\text { 3) intervention, } \\
\text { program }\end{array}$ & $\begin{array}{l}\text { 1) school-based or } \\
\text { after-school } \\
\text { 2) physical } \\
\text { activity } \\
\text { interventions or } \\
\text { prevention } \\
\text { programs } \\
\text { 3) obesity or } \\
\text { overweight } \\
\text { 4) child or } \\
\text { adolescent } \\
\text { 5) BMI or body } \\
\text { composition or } \\
\text { body fat }\end{array}$ & $\begin{array}{l}\text { 1) afterschool } \\
\text { (freetext terms } \\
\text { after school and } \\
\text { extra-curricular) } \\
\text { 2) physical } \\
\text { activity (MeSH } \\
\text { terms sports and } \\
\text { exercise, free-text } \\
\text { word sport, } \\
\text { exercise and } \\
\text { physical activity) } \\
\text { 3) children } \\
\text { (MeSH terms } \\
\text { Child and } \\
\text { Adolescent, } \\
\text { free-text } \\
\text { words "child*" } \\
\text { or teenager or } \\
\text { adolescent) }\end{array}$ \\
\hline
\end{tabular}




\section{Continued}

im of the review

Inclusion criteria
To examine

effects of studies

designed to

promote

physical activity

for children and

To examine

effects of

after-school

adolescents, either

as a sole

intervention or as

programmes on

children's

physical

activity.
To examine

effectiveness of

interventions to

promote physical

activity in young

people conducted

immediately after school.
To review obesity prevention programs implemented during the after school period.
To examine effects of after-school intervention programmes on the BMI of children and adolescents.
To examine

effectiveness of after-school interventions on increasing MVPA in children and adolescents. physical

activity),

during

after-school

hours in schools.

1) Setting: school (public or private)

2) Programme: after-school

3) Design: quasi-experimental (pre- and post-tests with no control or randomization) or RCT

4) Aim of included studies: primary component or one component to promote physical activity

5) Sample: children and adolescents (aged $\leq 18$ years)

6) Outcome measures: physical activity and/or physical fitness 7) Language: English

8) Intervention duration: not mentioned 9) Publication

dates: between 1980 and

February 2008
1) Setting: not mentioned

2) Programme: after-school 3) Design: not mentioned

4) Aim of included studies: to promote physical activity or prevent overweight/obesity 5) Sample: children and adolescents (aged $\leq 18$ years)

6) Outcome measures: physical activity (objective or self-report) and physical fitness

7) Language: not mentioned

8) Intervention duration: not mentioned

9) Publication dates: between 1990 and March 2010
1) Setting: not mentioned 2) Programme: after-school 3) Design: randomized

1) Setting: not mentioned 2) Programme: after-school 3) Design: not mentioned

4) Aim of included studies: primary prevention of childhood obesity 5) Sample: children

6) Outcome measures: not mentioned

7) Language: English

8) Intervention duration: not mentioned 9) Publication dates: between 2006 and September 2011 controlled trials or nonrandomized clinical trials with group not included in any intervention

4) Aim of included studies: increase PA, change and control children's diet, reduce sedentary activity 5) Sample: children and adolescents (aged $<19$ years) 6) Outcome measures: BMI body fat.

7) Language: not mentioned

8) Intervention duration: at least 6 weeks

9) Publication

dates: not

mentioned
1) Setting: school

2) Programme:

after-school

3) Design: quasi-experimental, pilot, non-randomised, and randomised trials 4) Aim of included studies: increase physical activity 5) Sample: young people aged 5 - 18 years

6) Outcome measures: time in moderate-to-vigorous physical activity (MVPA)

7) Language: English 8) Intervention duration: not mentioned 9) Publication dates: between 1950-2015 


\section{Continued}

\begin{tabular}{|c|c|c|c|c|c|}
\hline \multirow{7}{*}{$\begin{array}{l}\text { Exclusion } \\
\text { criteria }\end{array}$} & $\begin{array}{l}\text { 1) Descriptive only } \\
\text { articles }\end{array}$ & \multirow{7}{*}{$\begin{array}{l}\text { 1) Obesity } \\
\text { treatment studies } \\
\text { 2) Unpublished } \\
\text { articles, } \\
\text { conference papers, } \\
\text { dissertations }\end{array}$} & & $\begin{array}{l}\text { 1) Descriptive } \\
\text { articles only }\end{array}$ & \multirow{7}{*}{$\begin{array}{l}\text { 1) Conference } \\
\text { abstracts } \\
\text { 2) Unpublishec } \\
\text { articles } \\
\text { 3) Dissertation } \\
\text { 4) Non-English } \\
\text { papers }\end{array}$} \\
\hline & $\begin{array}{l}\text { 2) Articles without } \\
\text { results }\end{array}$ & & $\begin{array}{l}\text { 1) Articles } \\
\text { without data }\end{array}$ & $\begin{array}{l}\text { 2) Interventions } \\
\text { on diets only }\end{array}$ & \\
\hline & 3) Interventions & & results & $\begin{array}{l}\text { 3) Studies } \\
\text { involving }\end{array}$ & \\
\hline & without separate & & 2) Articles with & children & \\
\hline & findings for & & only baseline data & suffering from & \\
\hline & $\begin{array}{l}\text { attending an } \\
\text { after-school }\end{array}$ & & & eating disorders & \\
\hline & programme & & & $\begin{array}{l}\text { or drug or } \\
\text { alcohol problems }\end{array}$ & \\
\hline
\end{tabular}

Assessed using NICE tool for randomized trials

Quality None stated None stated

control (i.e., 10 internal validity items such as study design and sample size)
None stated
Adapted version of the Quality

Assessment Tool for Quantitative Studies (e.g., selection bias, blinding)

Studies

included

$\mathrm{n}=12$

$\mathrm{n}=13$

$\mathrm{n}=9$

$\mathrm{n}=21$

$\mathrm{n}=15$

$\mathrm{n}=15$

(Number)

Number of

studies

based on a

Not mentioned $\quad n=5$

$\mathrm{n}=6$

$\mathrm{n}=8$

$\mathrm{n}=2$

$\mathrm{n}=8$

theory

Participant

age (years)

$8-12$

$\leq 18$

$5-15$

Kindergarten

through middle

school, average

age 9 to 10 years $\leq 19$

$5-18$

randomised controlled trials (RCTs) and two (Kelder et al., 2005; Kien \& Chiodo, 2003) five quasi-experimental studies reporting significant positive intervention effects.

Beets et al. (2009) examined the effects of after-school programmes on a broad range of outcome variables and included 13 studies in a meta-analysis. All the studies were carried out in the school setting, but not all measured the same variables. Weighted pooled effect sizes indicated a small but positive impact on physical activity $(\mathrm{ES}=0.44$; range 0.19 to 0.70$)$, sedentary behaviour $(\mathrm{ES}=0.20)$, and other health-related outcomes (body composition, ES $=0.07$; fitness, ES = 0.16; blood lipids, ES =0.20; psychological determinants, $\mathrm{ES}=0.08$ ). Of the six studies reporting physical activity outcomes (Barbeau et al., 2007; Hermann et 
al., 2006; Lubans \& Morgan, 2008; Robinson et al., 2003; Story et al., 2003; Weintraub et al., 2008), three (50\%) showed significant positive effects (Barbeau et al., 2007; Hermann et al., 2006; Weintraub et al., 2008). Two of the three successful interventions on physical activity were assessed using self-reported physical activity measures (Barbeau et al., 2007; Hermann et al., 2006) and these had higher effect sizes ( 0.70 and 0.55$)$ than the third study that used accelerometers (0.43) (Weintraub et al., 2008). Four of six studies (66.6\%) that measured physical fitness reported significant improvements. One study (Martínez Vizcaíno et al., 2008), however, found the control group had a greater decrease in diastolic and systolic blood pressure than the intervention group (overall effect size: 0.16; $0.4 \mathrm{~mm} \mathrm{Hg}$ increase for the intervention group versus a $4.1 \mathrm{~mm} \mathrm{Hg}$ decrease in the control group in systolic blood pressure). The authors of the original study (Martínez Vizcaíno et al., 2008) did not identify possible reasons for this unexpected effect.

Ten studies reported outcomes related to body composition, with three (30\%) reporting reductions in BMI, body weight, or skinfold thickness for the intervention groups (overall effect size: 0.07). Two of three studies that reported blood lipid changes found significant positive effects. Four studies reported findings related to psychosocial constructs (e.g., body weight concerns, self-esteem, depression, self-efficacy, motivation, and parental support for physical activity) with an overall effect size of 0.08; only the Kelder et al. (2005) study, which analysed self-efficacy toward activity participation, reported a significant effect size for improved psychological outcomes (1.19). Only one of the four studies that investigated sedentary behaviour was effective in reducing it (overall effect size: 0.20$)$.

Atkin et al. (2011) reviewed nine studies that examined the effects of afterschool programmes on physical activity levels. Three of these were conducted in school settings, four in a combination of schools, community centres, or homes, one in a community centre and homes, and one solely in a community centre. Three studies were RCTs, one was a cluster randomised controlled trial, four were controlled non-randomised trials, and one was a pre-post study without a control group. Of the nine studies, three (33.3\%) reported a significant intervention increase in physical activity relative to controls (Taylor et al., 2007; Taylor et al., 2006; Weintraub et al., 2008; Wilson et al., 2005). A further two studies (Robinson et al., 2003; Story et al., 2003), both from a single project (GEMS), reported a trend toward having an intervention effect.

Branscum and Sharma (2012) reviewed 21 studies, 12 of them conducted in schools and nine in community centres or YMCA after-school centres. One third ( $n=7$ ) were RCTs, eight were quasi-experimental studies, and six were pilot studies. Seven of the 11 studies (63.6\%) that measured physical activity reported a significant positive effect. Six of nine studies $(66.6 \%)$ that measured physical fitness reported a significant change, as did ten of 18 studies $(55.5 \%)$ that measured BMI. Finally, three of the eight studies (37.5\%) that assessed psychological variables related to physical activity indicated a significant change in 
these constructs.

Vasques et al. (2014) reviewed 15 studies and conducted a meta-analysis on the effects of physical activity in during- and after-school interventions on BMI. Eight studies (53.3\%) showed significant positive changes on body composition, one showed a significant negative effect, and six identified no effect. Effect sizes for BMI ranged from $r=-0.97$ (Weintraub et al., 2008) to $r=0.59$ (Dzewaltowski et al., 2010) and there was an overall small but positive effect size $(r=0.065)^{1}$ on BMI. The authors did not provide details on the intervention settings.

Mears and Jago (2016) reviewed 15 studies and published the most recent meta-analysis on the effectiveness of after-school interventions on moderate-tovigorous physical activity (MVPA) in 5- to 18-year olds. Their review, in contrast to the others, included only studies that assessed the MVPA of individuals and excluded studies reporting only group-level outcomes or volume of physical activity. Their review included nine RCTs, five pilot RCTs and one cross-sectional RCT. The remaining six studies were quasi-experimental, longitudinal, or cross-sectional. Twelve studies used accelerometers to measure MVPA, two used self-reports, and one used heart rate monitoring. Six studies were included in the meta-analysis, five of which used accelerometry and one used self-reports. Based on these six, there was an overall increase of $4.84 \mathrm{~min} /$ day of MVPA (95\% CI -0.94 to 10.61) (i.e., the adjusted mean difference in min/day of MVPA in the intervention versus control group from baseline to follow-up). The greatest difference in mean MVPA (22.2 min/day, 95\% CI 9.6 to 34.2, p =0.0006) was reported for the study using self-reported outcomes (Barbeau et al., 2007). For accelerometer-based data, the largest significant mean difference in MVPA from baseline to follow-up was $10.5 \mathrm{~min} /$ day (95\% CI 1.5 to $18.6, \mathrm{p}=0.017$ ) and favoured the intervention group (Gortmaker et al., 2012).

\subsection{Moderators of the Effects of After-School Programmes}

Vasques et al. (2014) conducted a formal analysis to explore the potential moderating or facilitating factors associated with increased chances of programme success (see Table 2). They reported greater improvements in BMI for girls and older children and for longer, more frequent, and more intensive interventions. Additionally, they found the magnitude of the effects on BMI produced by both school $(r=0.069)$ and after-school $(r=0.065)$ interventions to be similar. Mears and Jago (2016) found no convincing evidence that interventions based on theories of behaviour change were more effective in improving physical activity levels than those using no underlying theory. Further subgroup analyses in their review revealed specific improvements in physical activity for overweight/obese children in three studies (Dzewaltowski et al., 2010; Iversen, Nigg, \& Titchenal, 2011; Madsen, Thompson, Adkins, \& Crawford, 2013) and for boys in two studies (Jago et al., 2014; Schuna Jr., Lauersdorf, Behrens, Liguori, \& Liebert, 2013).

Three of the six reviews considered in this paper compared indicators of obesity

${ }^{1}$ According to Cohen effect sizes for significance of product moment correlation coefficient (r) are: $0.10,0.30$, and 0.50 , for small, medium, and large, respectively. 
Table 2. Results of systematic reviews of after-school physical activity programmes on physical activity and health.

\begin{tabular}{|c|c|c|c|c|c|c|}
\hline & $\begin{array}{l}\text { Pate \& O'Neill } \\
(2009)\end{array}$ & $\begin{array}{l}\text { Beets et al. } \\
(2009)\end{array}$ & $\begin{array}{l}\text { Atkin et al. } \\
(2011)\end{array}$ & $\begin{array}{l}\text { Branscum \& } \\
\text { Sharma } \\
(2012)\end{array}$ & Vasques et al. (2014) & $\begin{array}{l}\text { Mears \& Jago } \\
(2016)\end{array}$ \\
\hline $\begin{array}{l}\text { Effects on } \\
\text { physical } \\
\text { activity }\end{array}$ & $\begin{array}{l}4 / 12(33.3 \%) \\
\text { studies sig. } \\
\text { increased PA; } \\
8 / 12 \text { no effect } \\
3 / 9 \text { objective and } \\
1 / 3 \text { self-report } \\
\text { PA measurement } \\
\text { sig. increased PA } \\
\text { No ES provided }\end{array}$ & $\begin{array}{l}3 / 6(50 \%) \text { studies } \\
\text { sig. increased in } \\
\text { PA; } 3 / 6 \text { no effect } \\
2 / 3 \text { self-report } \\
1 / 3 \text { objective PA } \\
\text { measurement } \\
\text { ES }=0.44 \\
(0.19,0.70)\end{array}$ & $\begin{array}{l}3 / 9(33.3 \%) \text { sig. } \\
\text { increase in PA; } 6 / 9 \\
\text { no change in PA } \\
\text { No ES provided }\end{array}$ & $\begin{array}{l}7 / 11(63.6 \%) \\
\text { sig. increase } \\
\text { in PA, } 4 / 11 \\
\text { no effect } \\
\text { No ES } \\
\text { provided }\end{array}$ & Not examined & $\begin{array}{l}\text { Overall ES } \\
\text { (over } 6 \text { studies) } \\
7.04 \text { min/day of } \\
\text { MVPA ( } 95 \% \text { CI } \\
1.59 \text { to } 12.5 \text { ) and } \\
\text { I2 value of } \\
65.5 \% .\end{array}$ \\
\hline $\begin{array}{l}\text { Effects on } \\
\text { fitness }\end{array}$ & Not examined & $\begin{array}{l}4 / 6(66.6 \%) \text { sig. } \\
\text { increased fitness; } \\
1 / 6(16,6 \%) \\
\text { control group sig. } \\
\text { greater decreases } \\
\text { in diastolic and } \\
\text { systolic blood } \\
\text { pressure; } 1 / 6 \text { no } \\
\text { effect } \\
\text { ES }=0.16 \\
(0.01,0.30)\end{array}$ & Not examined & $\begin{array}{l}6 / 9(66.6 \%) \\
\text { sig. changes } \\
\text { in fitness; } 3 / 9 \\
\text { no effect } \\
\text { No ES } \\
\text { provided }\end{array}$ & Not examined & Not examined \\
\hline $\begin{array}{l}\text { Effects on } \\
\text { body } \\
\text { composition }\end{array}$ & Not examined & $\begin{array}{l}\text { 3/10 ( } 30 \%) \text { sig. } \\
\text { decreased BMI, } \\
\text { body weight, or } \\
\text { skinfold } \\
\text { thickness; } 7 / 10 \\
\text { no effect } \\
\text { ES }=0.07 \\
(0.03,0.12)\end{array}$ & Not examined & $\begin{array}{l}10 / 18 \\
(55.5 \%) \text { sig. } \\
\text { positive } \\
\text { changes on } \\
\text { body } \\
\text { composition, } \\
8 / 18 \text { no } \\
\text { effect } \\
\text { No ES } \\
\text { provided }\end{array}$ & $\begin{array}{l}8 / 15(53.3 \%) \text { sig. } \\
\text { positive changes on } \\
\text { body composition, } 1 / 15 \\
\text { sig. negative effect, } \\
6 / 15 \text { no effect } \\
\text { Overall ES (over } 15 \\
\text { studies) }(r)=-0.97 ; 0.59\end{array}$ & Not examined \\
\hline $\begin{array}{l}\text { Effects on } \\
\text { blood lipids }\end{array}$ & Not examined & $\begin{array}{l}2 / 2 \text { sig. improved } \\
\text { blood lipids } \\
\text { ES }=0.20 \\
(0.06,0.33)\end{array}$ & Not examined & $\begin{array}{l}\text { Not } \\
\text { examined }\end{array}$ & Not examined & Not examined \\
\hline $\begin{array}{l}\text { Effects on } \\
\text { psychosocial } \\
\text { constructs }\end{array}$ & Not examined & $\begin{array}{l}1 / 4(25 \%) \text { sig. } \\
\text { improved } \\
\text { self-efficacy } \\
\text { toward activity } \\
\text { participation; } 3 / 4 \\
\text { no effect } \\
\text { ES }=0.08 \\
(0.22,0.37)\end{array}$ & Not examined & $\begin{array}{l}\text { 3/8 }(37.5 \%) \\
\text { sig. positive } \\
\text { changes on } \\
\text { psychological } \\
\text { constructs, } \\
5 / 8 \text { no effect } \\
\text { No ES } \\
\text { provided }\end{array}$ & Not examined & Not examined \\
\hline $\begin{array}{l}\text { Effects on } \\
\text { sedentary } \\
\text { activities }\end{array}$ & Not examined & $\begin{array}{l}1 / 4(25 \%) \text { sig. } \\
\text { reduced } \\
\text { sedentary } \\
\text { behaviour; } 3 / 4 \text { no } \\
\text { effect } \\
\text { ES }=0.20 \\
(-0.04,0.44)\end{array}$ & Not examined & $\begin{array}{l}\text { Not } \\
\text { examined }\end{array}$ & Not examined & Not examined \\
\hline
\end{tabular}


Factors

associated

with

positive

outcomes
No information

information

Suggestions by review authors

only:

- No evidence that enjoyment of physical activity plays a critical role in youth physical activity levels

- Attendance levels: $\geq 40 \%$ attendance associated with greater improvement in physical fitness (e.g., cardiovascular) compared to control students. $<40 \%$ attendance was no better than controls

- No evidence combined physical activity and diet intervention to be more effective on body composition, blood lipids, and psychosocial weight concerns.
Suggestions by review authors only:

- Single-behaviour interventions may be most effective during these hours.

- Effective interventions located in school settings; non-effective interventions more likely to take place in combinations of school, home, and community venues.
No

information 
proved outcomes on BMI when a combined approach was used. Beets et al. (2009) found no differential effect between using a physical activity and diet intervention programme and a physical activity only intervention on body composition, blood lipids, and psychosocial weight concerns. However, children and adolescents who attended $40 \%$ or more of the after-school sessions showed greater improvement on fitness levels (e.g., cardiovascular fitness and strength) than those who attended fewer lessons (Beets et al., 2009).

\section{Discussion}

This review of reviews indicates there were meaningful differences among six published reviews that assessed the impact of after-school interventions on children's physical activity and health, especially in terms of studies included and conclusions drawn. In support of the potential for positive effects Beets et al. (2009), concluded after-school programmes were effective in improving the physical activity and health in children and adolescents, and Vasques et al. (2014) emphasised the interventions had a positive (albeit low magnitude) effect on preventing and decreasing obesity. In contrast, Atkin et al. (2011) concluded interventions to promote physical activity in the after-school setting to date were ineffective, but attributed this in part to weaknesses in methodology or implementation. Finally, Pate and O'Neill (2009), Branscum and Sharma (2012), and Mears and Jago (2016) reported that after-school physical activity interventions had mixed effectiveness on increasing physical activity levels and that no definitieve conclusions could yet be made regarding their efficacy. To summarize these results, we believe there is modest support for the effectiveness of after-school programmes on children's physical activity levels and body composition, however, the overall evidence remains inconclusive.

Information on some specific variables examined in the reviews provides direction for future programme implementation and research. There appeared to be advantages for conducting programmes in schools rather than community settings, providing sessions on two or more days of the week and over a longer period of time, and ensuring high programme attendance rates. Additionally, subgroup analyses indicated that improvements in physical activity were greater among overweight/obese children and boys, and that improvements in weightrelated outcomes were greater in girls. Therefore, adapting after-school programme content to suit the needs of particular groups, rather than offering a general programme for all participants, is worth exploring.

The moderation analyses fostered questions relative to whether or not physical activity should simultaneously targeted alongside the promotion of healthy eating. Based on the three reviews that explored this question (Atkin et al., 2011; Beets et al., 2009; Vasques et al., 2014), it appears that a combined approach has no clear effect on physical activity outcomes but it may have a greater effect on body composition. Meanwhile, increasing physical activity alone is unlikely to bring about significant changes in BMI (especially among those already at a healthy weight), so is logical to also include healthy eating as part of any inter- 
vention designed to impact overweight and health.

Numerous theories were applied to the design of the after school-school interventions in the studies, most commonly social cognitive theory $(n=23)$ and self-determination theory $(n=4)$. In their review, however, Mears and Jago (2016) reported that the interventions that were based on theories of behaviour change were no more effective than those that had no underlying theory. Some possible reasons for this finding could be that the theories they were not adequately put into action or that inappropriate theories were used. No comment on this is made by the original authors.

The Consolidated Standards of Reporting Trials (CONSORT) statement for randomised trials emphasises the need to provide details of the delivery and description of the different components of interventions (Liberati et al., 2009). Detailed information on the intervention content and the behaviour change techniques employed was missing in most of the studies identified. Hence, a clear link between the intervention components, the intervention setting, and changes in physical activity cannot be made. Obtaining quality process measures (e.g., frequency/duration of the programme, its content, who teaches/leads it, participant to leader ratio, space, equipment, attendance rates) is essential to fully assessing intervention programmes (McKenzie et al., 1995). Only through such detailed measures can the validity of a programme be identified and viable plans for disseminating it be made.

The number of studies within the six individual reviews ranged from nine to 21; overall 52 unique studies were included. No study was included in all six reviews, and most $(n=35)$ were included only in one review. Within the reviews of programmes that promoted physical activity (Atkin et al., 2011; Beets et al., 2009; Mears \& Jago, 2016; Pate \& O’Neill, 2009), only two studies were assessed in all four reviews and 25 studies were contained in only one review (see Supplementary Table S1).

In part, discrepancies in the results of reviews may be a result of a lack of availability of high quality studies. The review authors all called for additional high-quality research to be conducted, and this included greater attention being given to the theoretical rationale, fidelity of implementation, and use of objective measures of physical activity. Nonetheless, differences among the results of the reviews therefore stem in large part from them being largely based on different sets of empirical studies. The inclusion of dissimilar studies may be in part due to differences in the search engines, search terms used, inclusion criteria, and outcome focus. We now consider these factors in turn (see Table 2).

All six reviews used Medline or PubMed (which includes Medline), but their additional databases varied widely. The number of electronic databases searched within the reviews ranged from two (Pate \& O'Neill, 2009) to 17 (Atkin et al., 2011), but using more databases did not lead to the inclusion of additional relevant studies. As all reviews used Medline and PubMed, it is unlikely that the selection of different search engines was entirely responsible for the variations in studies selected. There were discrepancies in the search terms between the two 
reviews that analysed studies focusing primarily on reducing overweight and the four reviews of studies focusing primarily on increasing physical activity. Some variation in the selection of original studies can also be explained by the article publication dates covered in the reviews.

Overall, nine inclusion criteria for selecting studies were set by the researchers (see Table 2). Beets et al. (2009) and Mears and Jago (2016) included only programmes conducted in school settings whereas the other reviews did not set location boundaries (e.g., school, community centres, home, YMCA). Branscum and Sharma (2012) and Pate and O'Neill (2009) included only interventions with children (i.e., age $\leq 12$ years), whereas the other reviews also included adolescents. This could have influenced the overall conclusions of the review as age was found to be a moderator of efficacy (i.e., outcomes were better for 15 - 19 year olds). Nonetheless, the conclusions of the two reviews that had child-only studies did not match each other and the conclusions of the four reviews of studies with both children and adolescents differed from each other as well.

The primary aim of four reviews (Atkin et al., 2011; Beets et al., 2009; Mears \& Jago, 2016; Pate \& O'Neill, 2009) was to summarise the effects of programmes on promoting physical activity, whereas the two other reviews (Branscum \& Sharma, 2012; Vasques et al., 2014) included studies primarily targeting obesity prevention. Outcomes reported in the reviews included: physical activity, sedentary behaviour, body composition, blood lipids, and indicators of psychological wellbeing. Mears and Jago (2016) included only studies that analysed MVPA at the individual level, and thus, group-level outcome measures or studies reporting overall physical activity but not specifically in moderate-to-vigorous intensity physical activity were excluded. This difference in the inclusion criteria accounts for the substantial variation between Mears and Jago (2016) and the other five reviews.

Beyond differences in the selection of outcome measures and publication dates, the majority of the study inclusion criteria were similar (e.g., no variation in quality criteria, intervention type, geographical location, or study design requirements). Except for the Mears and Jago (2016) review, which assessed MVPA only, we could find no differences between the approaches taken by the reviews that could account for variation in their conclusions. The global increase in existing databases provides a challenge to finding all published studies in a single research field and thus synthesising results into a comprehensive review. Detailed guidelines for the overall conduct of systematic reviews do exist in the form of the PRISMA guidelines (Liberati et al., 2009) however, and consistency among reviews could be improved if these recommendations were followed more strictly. Only two of the current reviews (Mears \& Jago, 2016; Vasques et al., 2014) identified adopting the PRISMA guidelines; Atkin et al. (2011), however, indicated their review was conducted in accordance with guidelines developed by the National Institute for Health and Clinical Excellence (NICE). Consistency in the selection of studies for reviews is essential for obtaining reliable and accurate reflections of the evidence base and it needs to be improved in fu- 
ture reviews.

\section{Conclusion}

After-school programmes, which support the need for after-school childcare, have potential for contributing to children's physical activity accrual. This review of reviews, however, suggests there is currently only modest support of the benefits of the after-school programmes on child and adolescent physical activity levels and body composition and many questions remain unanswered. Nevertheless, based on these findings it is worth continuing research in this area. More specifically, it was shown that initiatives delivered within schools rather than in the wider community and programmes with more than two sessions per week have a greater potential for positive effects on increasing students' physical activity levels. Nevertheless, given the diversity of programme components, measurement techniques, and implementation methods, settings, and personnel who designed and implemented the reviewed programmes, the factors influencing the efficacy of after-school programmes remain largely unclear. There is further need to design, implement, and assess quality after-school interventions that target physical activity in diverse settings. Their assessment should include not only the use of objective measures of physical activity but also incorporate the collection of detailed process measures (McKenzie et al., 1995).

\section{Conflict of Interests}

The authors declare that there are no conflicts of interest.

\section{References}

Atkin, A., Gorely, T., Biddle, S., Cavill, N., \& Foster, C. (2011). Interventions to Promote Physical Activity in Young People Conducted in the Hours Immediately after School: A Systematic Review. International Journal of Behavioral Medicine, 18, 176-187. https://doi.org/10.1007/s12529-010-9111-Z

Barbeau, P., Johnson, M. H., Howe, C. A., Allison, J., Davis, C. L., Gutin, B., \& Lemmon, C. R. (2007). Ten Months of Exercise Improves General and Visceral Adiposity, Bone, and Fitness in Black Girls. Obesity, 15, 2077-2085. https://doi.org/10.1038/oby.2007.247

Beets, M. W., Beighle, A., Erwin, H. E., \& Huberty, J. L. (2009). After-School Program Impact on Physical Activity and Fitness: A Meta-Analysis. American Journal of Preventive Medicine, 36, 527-537. https://doi.org/10.1016/j.amepre.2009.01.033

Branscum, P., \& Sharma, M. (2012). After-School Based Obesity Prevention Interventions: A Comprehensive Review of the Literature. International Journal of Environmental Research and Public Health, 9, 1438-1457.

https://doi.org/10.3390/ijerph9041438

Branscum, P., Sharma, M., Wang, L. L., Wilson, B. R. A., \& Rojas-Guyler, L. (2013). A True Challenge for Any Superhero: An Evaluation of a Comic Book Obesity Prevention Program. Family \& Community Health: The Journal of Health Promotion \& Maintenance, 36, 63-76. https://doi.org/10.1097/FCH.0b013e31826d7607

Centers for Disease Control and Prevention (2013). Comprehensive School Physical Activity Programs: A Guide for Schools. Atlanta, GA. 
Cooper, A. R., Goodman, A., Page, A. S., Sherar, L. B., Esliger, D. W., van Sluijs, E. M. et al. (2015). Objectively Measured Physical Activity and Sedentary Time in Youth: The International Children's Accelerometry Database (ICAD). International Journal of Behavioral Nutrition and Physical Activity, 12, 113. https://doi.org/10.1186/s12966-015-0274-5

Davies, B. R., Wood, L., Banfield, K., Edwards, M. J., \& Jago, R. (2014). The Provision of Active After-School Clubs for Children in English Primary Schools: Implications for Increasing Children's Physical Activity. Open Journal of Preventive Medicine, 4, 598605 https://doi.org/10.4236/ojpm.2014.47069

Department of Education (2013). National Curriculum in England: Physical Education Programmes of Study. UK: Department of Education.

Deutscher Olympischer Sportbund (Ed.) (2006). DSB-Sprint-Studie: Eine Untersuchung zur Situation des Schulsports in Deutschland. Aachen: Meyer \& Meyer.

Dzewaltowski, D. A., Rosenkranz, R. R., Geller, K. S., Coleman, K. J., Welk, G. J., Hastmann, T. J., \& Milliken, G. A. (2010). HOP’N After-School Project: An Obesity Prevention Randomized Controlled Trial. International Journal of Behavioral Nutrition and Physical Activity, 7, 90. https://doi.org/10.1186/1479-5868-7-90

Gortmaker, S. L., Lee, R. M., Mozaffarian, R. S., Sobol, A. M., Nelson, T. F., Roth, B. A., \& Wiecha, J. L. (2012). Effect of an After-School Intervention on Increases in Children's Physical Activity. Medicine and Science in Sports and Exercise, 44, 450-457. https://doi.org/10.1249/MSS.0b013e3182300128

Hermann, J. R., Parker, S. P., Brown, B. J., Siewe, Y. J., Denney, B. A., \& Walker, S. J. (2006). After-School Gardening Improves Children's Reported Vegetable Intake and Physical Activity. Journal of Nutrition Education and Behavior, 38, 201-202. https://doi.org/10.1016/j.jneb.2006.02.002

Higgins, J. P., \& Green, S. (2008). Cochrane Handbook for Systematic Reviews of Interventions (Vol. 5). Hoboken, NJ: Wiley. https://doi.org/10.1002/9780470712184

Iversen, C. S. S., Nigg, C., \& Titchenal, C. A. (2011). The Impact of an Elementary After-School Nutrition and Physical Activity Program on Children's Fruit and Vegetable Intake, Physical Activity, and Body Mass Index: Fun 5. Hawaii Medical Journal, 70, $37-41$.

Jago, R., Sebire, S. J., Davies, B., Wood, L., Edwards, M. J., Banfield, K. et al. (2014). Randomised Feasibility Trial of a Teaching Assistant Led Extracurricular Physical Activity Intervention for 9 to 11 Year Olds: Action 3:30. International Journal of Behavioral Nutrition and Physical Activity, 11, 114. https://doi.org/10.1186/s12966-014-0114-Z

Kahan, D., \& McKenzie, T. L. (2015). The Potential and Reality of Physical Education in Controlling Overweight and Obesity. American Journal of Public Health, 105, 653-659. https://doi.org/10.2105/AJPH.2014.302355

Kalman, M., Inchley, J., Sigmundova, D., Iannotti, R. J., Tynjälä, J. A., Hamrik, Z. et al. (2015). Secular Trends in Moderate-to-Vigorous Physical Activity in 32 Countries from 2002 to 2010: A Cross-National Perspective. The European Journal of Public Health, 25, 37-40. https://doi.org/10.1093/eurpub/ckv024

Kelder, S., Hoelscher, D. M., Barroso, C. S., Walker, J. L., Cribb, P., \& Hu, S. (2005). The CATCH Kids Club: A Pilot After-School Study for Improving Elementary Students' Nutrition and Physical Activity. Public Health Nutrition, 8, 133-140. https://doi.org/10.1079/PHN2004678

Kien, C. L., \& Chiodo, A. R. (2003). Physical Activity in Middle School-Aged Children Participating in a School-Based Recreation Program. Archives of Pediatrics and Adolescent Medicine, 157, 811-815. https://doi.org/10.1001/archpedi.157.8.811

Liberati, A., Altman, D. G., Tetzlaff, J., Mulrow, C., Gøtzsche, P. C., Ioannidis, J. P. et al. 
(2009). The PRISMA Statement for Reporting Systematic Reviews and Meta-Analyses of Studies That Evaluate Health Care Interventions: Explanation and Elaboration. Annals of Internal Medicine, 151, W-65-W-94.

https://doi.org/10.7326/0003-4819-151-4-200908180-00136

Lubans, D., \& Morgan, P. (2008). Evaluation of an Extra-Curricular School Sport Programme Promoting Lifestyle and Lifetime Activity for Adolescents. Journal of Sports Sciences, 26, 519-529. https://doi.org/10.1080/02640410701624549

Madsen, K., Thompson, H., Adkins, A., \& Crawford, Y. (2013). School-Community Partnerships: A Cluster-Randomized Trial of an After-School Soccer Program. JAMA Pediatrics, 167, 321-326. https://doi.org/10.1001/jamapediatrics.2013.1071

Martínez Vizcaíno, V., Salcedo Aguilar, F., Franquelo Gutiérrez, R., Solera Martínez, M., Sánchez López, M., Serrano Martínez, S. et al. (2008). Assessment of an After-School Physical Activity Program to Prevent Obesity Among 9- to 10-Year-Old Children: A Cluster Randomized Trial. International Journal of Obesity, 32, 12-22.

https://doi.org/10.1038/sj.ijo.0803738

McKenzie, T. L., Strikmiller, P. K., Stone, E. J., Woods, S. E., Ehlinger, S. S., Romero, K. A., \& Budman, S. T. (1995). CATCH: Physical Activity Process Evaluation in a Multicenter Trial. Health Education Quarterly, Suppl 2, S73-S89.

Mears, R., \& Jago, R. (2016). Effectiveness of After-School Interventions at Increasing Moderate-to-Vigorous Physical Activity Levels in 5- to 18-Year Olds: A Systematic Review and Meta-Analysis. British Journal of Sports Medicine, 50, 1315-1324. https://doi.org/10.1136/bjsports-2015-094976

Pate, R. R., \& O’Neill, J. R. (2009). After-School Interventions to Increase Physical Activity among Youth. British Journal of Sports Medicine, 43, 14-18. https://doi.org/10.1136/bjsm.2008.055517

Poitras, V. J., Gray, C. E., Borghese, M. M., Carson, V., Chaput, J.-P., Janssen, I. et al. (2016). Systematic Review of the Relationships between Objectively Measured Physical Activity and Health Indicators in School-Aged Children and Youth. Applied Physiology, Nutrition, and Metabolism, 41, 197-239. https://doi.org/10.1139/apnm-2015-0663

Robinson, T. N., Killen, J. D., Kraemer, H. C., Wilson, D. M., Matheson, D. M., Haskell, W. L. et al. (2003). Dance and Reducing Television Viewing to Prevent Weight Gain in African-American Girls: The Stanford GEMS Pilot Study. Ethnicity and Disease, 13, 65-77.

Sallis, J. F., McKenzie, T. L., Beets, M. W., Beighle, A., Erwin, H., \& Lee, S. (2012). Physical Education's Role in Public Health: Steps Forward and Backward over 20 Years and HOPE for the Future. Research Quarterly for Exercise and Sport, 83, 125-135.

https://doi.org/10.1080/02701367.2012.10599842

Schuna Jr., J. M., Lauersdorf, R. L., Behrens, T. K., Liguori, G., \& Liebert, M. L. (2013). An Objective Assessment of Children's Physical Activity during the Keep It Moving! After-School Program. Journal of School Health, 83, 105-111.

https://doi.org/10.1111/josh.12005

Story, M., Sherwood, N. E., Himes, J. H., Davis, M., Jacobs Jr., D. R., Cartwright, Y. et al. (2003). An After-School Obesity Prevention Program for African-American Girls: The Minnesota GEMS Pilot Study. Ethnicity and Disease, 13, S54-S64.

Taylor, R. W., McAuley, K. A., Barbezat, W., Strong, A., Williams, S. M., \& Mann, J. I. (2007). APPLE Project: 2-y Findings of a Community-Based Obesity Prevention Program in Primary School Age Children. American Journal of Clinical Nutrition, 86, 735-742.

Taylor, R. W., McAuley, K. A., Williams, S. M., Barbezat, W., Nielsen, G., \& Mann, J. I. (2006). Reducing Weight Gain in Children through Enhancing Physical Activity and 
Nutrition: The APPLE Project. International Journal of Pediatric Obesity, 1, 146-152. https://doi.org/10.1080/17477160600881247

Telama, R., Yang, X., Viikari, J., Välimäki, I., Wanne, O., \& Raitakari, O. (2005). Physical Activity from Childhood to Adulthood: A 21-Year Tracking Study. American Journal of Preventive Medicine, 28, 267-273. https://doi.org/10.1016/j.amepre.2004.12.003

US Department of Health and Human Services (2013). Educating the Student Body: Taking Physical Activity and Physical Education to School. Washington DC: The National Academies Press.

U.S. Department of Health and Human Services (2015). Results from the School Health and Policies and Practices Study 2014. Atlanta, GA.

Vasques, C., Magalhães, P., Cortinhas, A., Mota, P., Leitão, J., \& Lopes, V. P. (2014). Effects of Intervention Programs on Child and Adolescent BMI: A Meta-Analysis Study. Journal of Physical Activity and Health, 11, 426-444. https://doi.org/10.1123/jpah.2012-0035

Weintraub, D. L., Tirumalai, E. C., Haydel, K. F., Fujimoto, M., Fulton, J. E., \& Robinson, T. N. (2008). Team Sports for Overweight Children: The Stanford Sports to Prevent Obesity Randomized Trial (SPORT). Archives of Pediatrics and Adolescent Medicine, 162, 232-237. https://doi.org/10.1001/archpediatrics.2007.43

WHO (2010). Global Recommendations on Physical Activity for Health. Geneva: WHO Press.

Wilson, D. K., Evans, A. E., Williams, J., Mixon, G., Sirard, J. R., \& Pate, R. (2005). A Preliminary Test of a Student-Centered Intervention on Increasing Physical Activity in Underserved Adolescents. Annals of Behavioral Medicine, 30, 119-124.

https://doi.org/10.1207/s15324796abm3002_4 


\section{Supplementary}

Table S1. Original papers included in the six reviews.

\begin{tabular}{|c|c|c|c|c|c|c|}
\hline & $\begin{array}{l}\text { Pate \& O’Neill } \\
(2009)\end{array}$ & Beets et al. (2009) & Atkin et al. (2011) & $\begin{array}{l}\text { Mears \& Jago } \\
(2016)\end{array}$ & $\begin{array}{l}\text { Branscum \& } \\
\text { Sharma (2012) }\end{array}$ & $\begin{array}{l}\text { Vasques et al. } \\
(2014)\end{array}$ \\
\hline 1 & & & & & & $\begin{array}{l}\text { Annesi, Pierce, } \\
\text { Bonaparte, \& Smith } \\
\text { (2009) }\end{array}$ \\
\hline 2 & & & Annesi et al. (2007) & & & \\
\hline 3 & & & & & Annesi (2006) & \\
\hline 4 & & & & & $\begin{array}{l}\text { Annesi, } \\
\text { Faigenbaum, } \\
\text { Westcott, \& Smith } \\
(2008)\end{array}$ & \\
\hline 5 & & & & & $\begin{array}{l}\text { Annesi, Moore, \& } \\
\text { Dixon (2008) }\end{array}$ & \\
\hline 6 & & & & & $\begin{array}{l}\text { Annesi, Tennant, } \\
\text { Westcott, } \\
\text { Faigenbaum, \& } \\
\text { Smith (2009) }\end{array}$ & \\
\hline 7 & & & & & $\begin{array}{l}\text { Annesi \& Vaughn } \\
(2011)\end{array}$ & \\
\hline 8 & & & & & $\begin{array}{l}\text { Branscum \& Kaye } \\
(2009)\end{array}$ & \\
\hline 9 & & & & & $\begin{array}{l}\text { Carson \& Reiboldt } \\
\text { (2011) }\end{array}$ & \\
\hline 10 & $\begin{array}{l}\text { Barbeau et al. } \\
(2007)\end{array}$ & $\begin{array}{l}\text { Barbeau et al. } \\
(2007)\end{array}$ & & $\begin{array}{l}\text { Barbeau et al. } \\
(2007)\end{array}$ & $\begin{array}{l}\text { Barbeau et al. } \\
(2007)\end{array}$ & $\begin{array}{l}\text { Barbeau et al. } \\
(2007)\end{array}$ \\
\hline 11 & & & & & $\begin{array}{l}\text { de Heer, Koehly, } \\
\text { Pederson, \& } \\
\text { Morera (2011) }\end{array}$ & \\
\hline 12 & & & & $\begin{array}{l}\text { Dzewaltowski et al. } \\
\text { (2010) }\end{array}$ & & $\begin{array}{l}\text { Dzewaltowski et al. } \\
(2010)\end{array}$ \\
\hline 13 & & $\begin{array}{l}\text { Lubans \& Morgan } \\
(2008)\end{array}$ & & & & \\
\hline 14 & Farley et al. (2007) & & & & & \\
\hline 15 & $\begin{array}{l}\text { Gutin, Yin, } \\
\text { Johnson, \& Barbeau } \\
(2008)\end{array}$ & $\begin{array}{l}\text { Gutin, Yin, } \\
\text { Johnson, \& Barbeau } \\
(2008)\end{array}$ & & & $\begin{array}{l}\text { Gutin, Yin, } \\
\text { Johnson, \& } \\
\text { Barbeau (2008) }\end{array}$ & \\
\hline 16 & & $\begin{array}{l}\text { Yin, Moore, et al. } \\
(2005)\end{array}$ & & & & $\begin{array}{l}\text { Yin, Moore, et al. } \\
(2005)\end{array}$ \\
\hline 17 & & & & & & \\
\hline 18 & & & & Iversen et al. (2011) & & \\
\hline 19 & & & & $\begin{array}{l}\text { Gortmaker et al. } \\
\text { (2012) }\end{array}$ & & \\
\hline
\end{tabular}




\section{Continued}

Kien \& Chiodo (2003)

27

Robinson et al.

(2008) (2008)

Speroni, Earley, \& Atherton (2007)

Vizcaino et al. 2008

40

41

42

43
Herrick,

Thompson, Kinder, \& Madsen (2012)

Howe, Harris, \& Gutin (2011)

Ignico \& Ethridge (1997)

Jago et al. (2012)

Kelder et al. (2005)

Melnyk et al. (2007)

(Taylor et al. (2007);

Taylor et al. (2006))

Pate et al. (2003)

Madsen et al. (2009)

adsen et al.

(2009)

Matvienko \&

Ahrabi-Fard (2010)

Melnyk et al.

(2007)

Neumark-Sztainer

Neumark-Sztainer et al. (2009) et al. (2009)
Schofield,

Mummery, \& Schofield (2005)

Speroni et al. (2007)

Story et al. (2003) Story et al. (2003)

Vizcaino et al.

(2008)

Weintraub et al.

(2008)
Weintraub et al. (2008)

Wilson et al. (2005)
Wilson et al. (2002)
(2008)

Wilson et al. (2002)

Wilson et al. (2011)
Story et al. (2003)

Vizcaino et al. (2008)

Weintraub et al. (2008) 


\section{Continued}

44

45

46

Robinson et al. (2003)

Hermann et al. (2006)

Cliff, Wilson,

Okely, Mickle, \&

Steele (2007)

Economos et al. (2007)

Goldfield et al. (2006)

(Robbins, Pfeiffer,

Maier, Lo, \&

Wesolek, 2012)

Robinson et al.

(2003)
Schuna Jr. et al.

(2013)

Slawta, Bentley, Smith, Kelly, \& Syman-Degler Slawta et al. (2008) (2008)

\section{Bibliography}

Alves, J. G. B., Gale, C. R., Souza, E., \& Batty, G. D. (2008). Effect of Physical Exercise on Bodyweight in Overweight Children: A Randomized Controlled Trial in a Brazilian Slum. Cadernos de Saude Publica, 24, S353-S359.

Annesi, J. J. (2006). Relations of Physical Self-Concept and Self-Efficacy with Frequency of Voluntary Physical Activity in Preadolescents: Implications for After-School Care Programming. Journal of Psychosomatic Research, 61, 515-520. https://doi.org/10.1016/j.jpsychores.2006.04.009

Annesi, J. J., \& Vaughn, L. L. (2011). Effects of Extension of the Youth Fit for Life Intervention Program by Video vs. Instructor Supervision. Archives of Exercise in Health \& Disease, 2, 102-107. https://doi.org/10.5628/aehd.v2i2.43

Annesi, J. J., Faigenbaum, A. D., Westcott, W. L., \& Smith, A. E. (2008). Relations of Self-Appraisal and Mood Changes with Voluntary Physical Activity Changes in African American Preadolescents in an After-School Care Intervention. Journal of Sports Science \& Medicine, 7, 260-268.

Annesi, J. J., Faigenbaum, A. D., Westcott, W. L., Smith, A. E., Unruh, J. L., \& Hamilton, F. G. (2007). Effects of the Youth Fit for Life Protocol on Physiological, Mood, Self-Appraisal, and Voluntary Physical Activity Changes in African American Preadolescents: Contrasting After-School Care and Physical Education Formats. International Journal of Clinical and Health Psychology, 7, 641-659.

Annesi, J. J., Moore, J. C., \& Dixon, G. M. (2008). Correlates of Changes in Voluntary Physical Activity Associated with the Youth Fit for Life (TM) Intervention during After-School Care. Psychological Reports, 102, 911-919. 
https://doi.org/10.2466/pr0.102.3.911-919

Annesi, J. J., Pierce, L. L., Bonaparte, W. A., \& Smith, A. E. (2009). Preliminary Effects of the Youth Fit for Life Protocol on Body Mass Index in Mexican American Children in YMCA Before- and After-School Care Programs. Hispanic Health Care International, 7, 123-129.

Annesi, J. J., Tennant, G., Westcott, W. L., Faigenbaum, A. D., \& Smith, A. E. (2009). Effects of the Youth Fit for Life Protocol on Physiological, Psychological, and Behavioral Factors at YMCA Calgary After-School Care Sites. Psychological Reports, 104, 879-895. https://doi.org/10.2466/PR0.104.3.879-895

Atkin, A., Gorely, T., Biddle, S., Cavill, N., \& Foster, C. (2011). Interventions to Promote Physical Activity in Young People Conducted in the Hours Immediately after School: A Systematic Review. International Journal of Behavioral Medicine, 18, 176-187. https://doi.org/10.1007/s12529-010-9111-Z

Barbeau, P., Johnson, M. H., Howe, C. A., Allison, J., Davis, C. L., Gutin, B., \& Lemmon, C. R. (2007). Ten Months of Exercise Improves General and Visceral Adiposity, Bone, and Fitness in Black Girls. Obesity, 15, 2077-2085. https://doi.org/10.1038/oby.2007.247

Beets, M. W., Beighle, A., Erwin, H. E., \& Huberty, J. L. (2009). After-School Program Impact on Physical Activity and Fitness: A Meta-Analysis. American Journal of Preventive Medicine, 36, 527-537. https://doi.org/10.1016/j.amepre.2009.01.033

Branscum, P., \& Kaye, G. (2009). An Evaluation of a Theory Based Childhood Overweight Prevention Curriculum. Californian Journal of Health Promotion, 7, 33-38.

Branscum, P., \& Sharma, M. (2012). After-School Based Obesity Prevention Interventions: A Comprehensive Review of the Literature. International Journal of Environmental Research and Public Health, 9, 1438-1457.

https://doi.org/10.3390/ijerph9041438

Carson, D. E., \& Reiboldt, W. (2011). An After-School Program on Nutrition and Physical Activity for Elementary School Children. Family and Consumer Sciences Research Journal, 39, 267-278. https://doi.org/10.1111/j.1552-3934.2010.02065.x

Cliff, D. P., Wilson, A., Okely, A. D., Mickle, K. J., \& Steele, J. R. (2007). Feasibility of SHARK: A Physical Activity Skill-Development Program for Overweight and Obese Children. Journal of Science and Medicine in Sport, 10, 263-267. https://doi.org/10.1016/j.jsams.2006.07.003

de Heer, H. D., Koehly, L., Pederson, R., \& Morera, O. (2011). Effectiveness and Spillover of an After-School Health Promotion Program for Hispanic Elementary School Children. American Journal of Public Health, 101, 1907-1913.

https://doi.org/10.2105/AJPH.2011.300177

Dzewaltowski, D. A., Rosenkranz, R. R., Geller, K. S., Coleman, K. J., Welk, G. J., Hastmann, T. J., \& Milliken, G. A. (2010). HOP’N After-School Project: An Obesity Prevention Randomized Controlled Trial. International Journal of Behavioral Nutrition and Physical Activity, 7, 90. https://doi.org/10.1186/1479-5868-7-90

Economos, C. D., Hyatt, R. R., Goldberg, J. P., Must, A., Naumova, E. N., Collins, J. J., \& Nelson, M. E. (2007). A Community Intervention Reduces BMI z-Score in Children: Shape up Somerville First Year Results. Obesity, 15, 1325-1336.

https://doi.org/10.1038/oby.2007.155

Farley, T. A., Meriwether, R. A., Baker, E. T., Watkins, L. T., Johnson, C. C., \& Webber, L. S. (2007). Safe Play Spaces to Promote Physical Activity in Inner-City Children: Results from a Pilot Study of an Environmental Intervention. American Journal of Public Health, 97, 1625-1631. https://doi.org/10.2105/ajph.2006.092692

Goldfield, G. S., Mallory, R., Parker, T., Cunningham, T., Legg, C., Lumb, A. et al. (2006). 
Effects of Open-Loop Feedback on Physical Activity and Television Viewing in Overweight and Obese Children: A Randomized, Controlled Trial. Pediatrics, 118, E157E166. https://doi.org/10.1542/peds.2005-3052

Gortmaker, S. L., Lee, R. M., Mozaffarian, R. S., Sobol, A. M., Nelson, T. F., Roth, B. A., \& Wiecha, J. L. (2012). Effect of an After-School Intervention on Increases in Children's Physical Activity. Medicine and Science in Sports and Exercise, 44, 450-457. https://doi.org/10.1249/MSS.0b013e3182300128

Gutin, B., Yin, Z., Johnson, M., \& Barbeau, P. (2008). Preliminary Findings of the Effect of a 3-Year After-School Physical Activity Intervention on Fitness and Body Fat: The Medical College of Georgia Fitkid Project. International Journal of Pediatric Obesity, 3, 3-9. https://doi.org/10.1080/17477160801896457

Hermann, J. R., Parker, S. P., Brown, B. J., Siewe, Y. J., Denney, B. A., \& Walker, S. J. (2006). After-School Gardening Improves Children's Reported Vegetable Intake and Physical Activity. Journal of Nutrition Education and Behavior, 38, 201-202. https://doi.org/10.1016/j.jneb.2006.02.002

Herrick, H., Thompson, H., Kinder, J., \& Madsen, K. A. (2012). Use of SPARK to Promote After-School Physical Activity. Journal of School Health, 82, 457-461. https://doi.org/10.1111/j.1746-1561.2012.00722.x

Howe, C. A., Harris, R. A., \& Gutin, B. (2011). A 10-Month Physical Activity Intervention Improves Body Composition in Young Black Boys. Journal of Obesity, 2011, Article ID: 358581. https://doi.org/10.1155/2011/358581

Ignico, A. A., \& Ethridge, K. (1997). The Effects of a Physical Activity Program on Low-Fit Children's Activity Level and Aerobic Endurance. Early Child Development and Care, 135, 103-108. https://doi.org/10.1080/0300443971350108

Iversen, C. S. S., Nigg, C., \& Titchenal, C. A. (2011). The Impact of an Elementary After-School Nutrition and Physical Activity Program on Children's Fruit and Vegetable Intake, Physical Activity, and Body Mass Index: Fun 5. Hawaii Medical Journal, 70, 37-41.

Jago, R., Sebire, S. J., Cooper, A. R., Haase, A. M., Powell, J., Davis, L. et al. (2012). Bristol Girls Dance Project Feasibility Trial: Outcome and Process Evaluation Results. The International Journal of Behavioral Nutrition and Physical Activity, 9, 83. https://doi.org/10.1186/1479-5868-9-83

Kelder, S., Hoelscher, D. M., Barroso, C. S., Walker, J. L., Cribb, P., \& Hu, S. (2005). The CATCH Kids Club: A Pilot After-School Study for Improving Elementary Students' Nutrition and Physical Activity. Public Health Nutrition, 8, 133-140. https://doi.org/10.1079/PHN2004678

Kien, C. L., \& Chiodo, A. R. (2003). Physical Activity in Middle School-Aged Children Participating in a School-Based Recreation Program. Archives of Pediatrics and Adolescent Medicine, 157, 811-815. https://doi.org/10.1001/archpedi.157.8.811

Lazaar, N., Aucouturier, J., Ratel, S., Rance, M., Meyer, M., \& Duche, P. (2007). Effect of Physical Activity Intervention on Body Composition in Young Children: Influence of Body Mass Index Status and Gender. Acta Paediatrica, 96, 1315-1320. https://doi.org/10.1111/j.1651-2227.2007.00426.x

Lubans, D., \& Morgan, P. (2008). Evaluation of an Extra-Curricular School Sport Programme Promoting Lifestyle and Lifetime Activity for Adolescents. Journal of Sports Sciences, 26, 519-529. https://doi.org/10.1080/02640410701624549

Madsen, K. A., Thompson, H. R., Wlasiuk, L., Queliza, E., Schmidt, C., \& Newman, T. B. (2009). After-School Program to Reduce Obesity in Minority Children: A Pilot Study. Journal of Child Health Care, 13, 333-346. https://doi.org/10.1177/1367493509344823

Matvienko, O., \& Ahrabi-Fard, I. (2010). The Effects of a 4-Week After-School Program 
on Motor Skills and Fitness of Kindergarten and First-Grade Students. American Journal of Health Promotion, 24, 299-303.

Mears, R., \& Jago, R. (2016). Effectiveness of After-School Interventions at Increasing Moderate-to-Vigorous Physical Activity Levels in 5- to 18-Year Olds: A Systematic Review and Meta-Analysis. British Journal of Sports Medicine, 50, 1315-1324. https://doi.org/10.1136/bjsports-2015-094976

Melnyk, B. M., Small, L., Morrison-Beedy, D., Strasser, A., Spath, L., Kreipe, R. et al. (2007). The COPE Healthy Lifestyles TEEN Program: Feasibility, Preliminary Efficacy, \& Lessons Learned from an after School Group Intervention with Overweight Adolescents. Journal of Pediatric Health Care, 21, 315-322.

https://doi.org/10.1016/j.pedhc.2007.02.009

Neumark-Sztainer, D., Haines, J., Robinson-O’Brien, R., Hannan, P. J., Robins, M., Morris, B., \& Petrich, C. A. (2009). "Ready. Set. ACTION!” A Theater-Based Obesity Prevention Program for Children: A Feasibility Study. Health Education Research, 24, 407-420. https://doi.org/10.1093/her/cyn036

Pate, R. R., \& O’Neill, J. R. (2009). After-School Interventions to Increase Physical Activity among Youth. British Journal of Sports Medicine, 43, 14-18. https://doi.org/10.1136/bjsm.2008.055517

Pate, R. R., Saunders, R. P., Ward, D. S., Felton, G., Trost, S. G., \& Dowda, M. (2003). Evaluation of a Community-Based Intervention to Promote Physical Activity in Youth: Lessons from Active Winners. American Journal of Health Promotion, 17, 171-182.

Robbins, L. B., Pfeiffer, K. A., Maier, K. S., Lo, Y. J., \& Wesolek, S. M. (2012). Pilot Intervention to Increase Physical Activity among Sedentary Urban Middle School Girls: A Two-Group Pretest-Posttest Quasi-Experimental Design. Journal of School Nursing, 28, 302-315. https://doi.org/10.1177/1059840512438777

Robinson, T. N., Killen, J. D., Kraemer, H. C., Wilson, D. M., Matheson, D. M., Haskell, W. L. et al. (2003). Dance and Reducing Television Viewing to Prevent Weight Gain in African-American Girls: The Stanford GEMS Pilot Study. Ethnicity and Disease, 13, 65-77.

Robinson, T. N., Kraemer, H. C., Matheson, D. M., Obarzanek, E., Wilson, D. M., Haskell, W. L. et al. (2008). Stanford GEMS Phase 2 Obesity Prevention Trial for Low-Income African-American Girls: Design and Sample Baseline Characteristics. Contemporary Clinical Trials, 29, 56-69. https://doi.org/10.1016/j.cct.2007.04.007

Schofield, L., Mummery, W. K., \& Schofield, G. (2005). Effects of a Controlled Pedometer-Intervention Trial for Low-Active Adolescent Girls. Medicine and Science in Sports and Exercise, 37, 1414-1420. https://doi.org/10.1249/01.mss.0000174889.89600.e3

Schuna Jr., J. M., Lauersdorf, R. L., Behrens, T. K., Liguori, G., \& Liebert, M. L. (2013). An Objective Assessment of Children's Physical Activity during the Keep It Moving! After-School Program. Journal of School Health, 83, 105-111.

https://doi.org/10.1111/josh.12005

Slawta, J., Bentley, J., Smith, J., Kelly, J., \& Syman-Degler, L. (2008). Promoting Healthy Lifestyles in Children: A Pilot Program of Be a Fit Kid. Health Promotion Practice, 9, 305-312. https://doi.org/10.1177/1524839906289221

Speroni, K. G., Earley, C., \& Atherton, M. (2007). Evaluating the Effectiveness of the Kids Living Fit ${ }^{\mathrm{Tm}}$ Program: A Comparative Study. The Journal of School Nursing, 23, 329336. https://doi.org/10.1177/10598405070230060501

Story, M., Sherwood, N. E., Himes, J. H., Davis, M., Jacobs Jr., D. R., Cartwright, Y. et al. (2003). An After-School Obesity Prevention Program for African-American Girls: The Minnesota GEMS Pilot Study. Ethnicity and Disease, 13, S54-S64.

Taylor, R. W., McAuley, K. A., Barbezat, W., Strong, A., Williams, S. M., \& Mann, J. I. 
(2007). APPLE Project: 2-y Findings of a Community-Based Obesity Prevention Program in Primary School Age Children. American Journal of Clinical Nutrition, 86, 735-742.

Taylor, R. W., McAuley, K. A., Williams, S. M., Barbezat, W., Nielsen, G., \& Mann, J. I. (2006). Reducing Weight Gain in Children through Enhancing Physical Activity and Nutrition: The APPLE Project. International Journal of Pediatric Obesity, 1, 146-152. https://doi.org/10.1080/17477160600881247

Topp, R., Jacks, D. E., Wedig, R. T., Newman, J. L., Tobe, L., \& Hollingsworth, A. (2009). Reducing Risk Factors for Childhood Obesity. The Tommie Smith Youth Athletic Initiative. Western Journal of Nursing Research, 31, 715-730. https://doi.org/10.1177/0193945909336356

Vasques, C., Magalhães, P., Cortinhas, A., Mota, P., Leitão, J., \& Lopes, V. P. (2014). Effects of Intervention Programs on Child and Adolescent BMI: A Meta-Analysis Study. Journal of Physical Activity and Health, 11, 426-444.

https://doi.org/10.1123/jpah.2012-0035

Vizcaino, V. M., Aguilar, F. S., Gutierrez, R. F., Martinez, M. S., Lopez, M. S., Martinez, S. S. et al. (2008). Assessment of an After-School Physical Activity Program to Prevent Obesity among 9- to 10-Year-Old Children: A Cluster Randomized Trial. International Journal of Obesity, 32, 12-22. https://doi.org/10.1038/sj.ijo.0803738

Weintraub, D. L., Tirumalai, E. C., Haydel, K. F., Fujimoto, M., Fulton, J. E., \& Robinson, T. N. (2008). Team Sports for Overweight Children: The Stanford Sports to Prevent Obesity Randomized Trial (SPORT). Archives of Pediatrics and Adolescent Medicine, 162, 232-237. https://doi.org/10.1001/archpediatrics.2007.43

Wilson, D. K., Evans, A. E., Williams, J., Mixon, G., Sirard, J. R., \& Pate, R. (2005). A Preliminary Test of a Student-Centered Intervention on Increasing Physical Activity in Underserved Adolescents. Annals of Behavioral Medicine, 30, 119-124.

https://doi.org/10.1207/s15324796abm3002_4

Wilson, D. K., Friend, R., Teasley, N., Green, S., Reaves, I. L., \& Sica, D. A. (2002). Motivational versus Social Cognitive Interventions for Promoting Fruit and Vegetable Intake and Physical Activity in African American Adolescents. Annals of Behavioral Medicine, 24, 310-319. https://doi.org/10.1207/S15324796ABM2404_07

Wilson, D. K., Lee Van Horn, M., Kitzman-Ulrich, H., Saunders, R., Pate, R., Lawman, H. G. et al. (2011). Results of the "Active by Choice Today" (ACT) Randomized Trial for Increasing Physical Activity in Low-Income and Minority Adolescents. Health Psychology, 30, 463-471. https://doi.org/10.1037/a0023390

Yin, Z., Gutin, B., Johnson, M. H., Hanes, J., Moore, J. B., Cavnar, M. et al. (2005). An Environmental Approach to Obesity Prevention in Children: Medical College of Georgia FitKid Project Year 1 Results. Obesity Research, 13, 2153-2161. https://doi.org/10.1038/oby.2005.267

Yin, Z., Moore, J. B., Johnson, M. H., Barbeau, P., Cavnar, M., Thornburg, J., \& Gutin, B. (2005). The Medical College of Georgia Fitkid Project: The Relations between Program Attendance and Changes in Outcomes in Year 1. International Journal of Obesity, 29, S40-S45. https://doi.org/10.1038/sj.ijo.0803061 
Submit or recommend next manuscript to SCIRP and we will provide best service for you:

Accepting pre-submission inquiries through Email, Facebook, LinkedIn, Twitter, etc. A wide selection of journals (inclusive of 9 subjects, more than 200 journals)

Providing 24-hour high-quality service

User-friendly online submission system

Fair and swift peer-review system

Efficient typesetting and proofreading procedure

Display of the result of downloads and visits, as well as the number of cited articles Maximum dissemination of your research work

Submit your manuscript at: http://papersubmission.scirp.org/

Or contact ape@scirp.org 